\title{
PRODUCTIVITY OF DIATOMS IN CULTURE AND IN MARINE HABITATS
}

\author{
by \\ DIETRICH WERNER ${ }^{1)}$ and RICHARD ROTH ${ }^{1)}$
}

\begin{abstract}
ABSIRACT
The diatom dominated phytoplankton net primary production in different areas of the ocean (from 100-1000 mg C. $\mathrm{m}^{-2}$. day ${ }^{-1}$ ) and in estuaries (up to $2000{\mathrm{mg} \mathrm{C} . \mathrm{m}^{-2} \text {. day }}^{-1}$ ) is compared with the maximum productivity of marine diatoms in culture $\left(50 \mathrm{~g} \mathrm{C} . \mathrm{m}^{-2}\right.$. day $\left.{ }^{-1}\right)$ for Cyclotella cryptica (Centrales, Diatomeae) and $1000 \mathrm{mg} \mathrm{C} \cdot \mathrm{m}^{-2} \cdot \mathrm{day}^{-1}$ for Coscinodiscus asteromphalus (Centrales, Diatomeae). The rate of $\mathrm{C}$-assimilation as a measure of primary production is critically discussed in relation to the different factors regulating the reproduction of cells and the production of organic material. The evaluation of another parameter for primary production: light dependent protein synthesis (LPS) is proposed, which brings reproduction of phytoplankton cells and the production of organic material closer together. As an example of the requirement for more information about the potential growth and production rate of diatom species, some results on the cultivation of the tropical shallow water diatom Bellerochea yucatanensis V. STOSCH (Centrales, Diatomeae) are presented. At $30 \mathrm{C}$ this species has a specific growth rate $(\mu \max )$ of $=4.4$ divisions per day and 4 divisions per day at $34^{\circ} \mathrm{C}$ with an average cell size of $34 \times 26 \mu \mathrm{m}$. The temperature range of this species is from $12^{\circ} \mathrm{C}(\mu=0.3)$ to $35^{\circ} \mathrm{C}(\mu=2)$.
\end{abstract}

\section{MATERIALS AND METHODS}

The cultivation of Bellerochea yucatanensis V. STOSCH (V. STOSCH 1976) was as described by WERNER \& STANGIER (1976) with the following variation: the sea water medium (medium No. $14 \mathrm{~A}$ ) was buffered with $0.02 \mathrm{M}$ TRIS-HC1 pH 8.0 (medium No. $14 \mathrm{~B}$ ). In cultures with continuous aeration, the suspensions were bubbled with $1.5 \%(\mathrm{v} / \mathrm{v}) \mathrm{CO}_{2}$ in air in culture vessels in a KNIESE-lightthermostat, as described by WERNER (1966). Despite the buffering, the pH fell from 8.0 to 7.4 in the cultures bubbled with $1,5 \% \mathrm{CO}_{2}$ in air (without diatoms in the medium), but remains constant in cultures not additionally aerated (a layer of about $20 \mathrm{~mm}$ medium in $50 \mathrm{ml}$ Erlenmeyer flasks was used). Photosynthesis was measured according to WERNER (1966), ${ }^{14} \mathrm{C}$-sodium carbonate uptake was determined as described by WERNER (1971 c). 


\section{DIETRICH WERNER \& RICHARD ROTH}

\section{RESULTS AND DISCUSSION}

1. A comparison of production in culture and in marine habitats

The comparison of production rates in different parts of the oceans with that achieved in small and large scale cultures of marine phytoplankton species can give us some information about the potential primary production of a given water column without nutrient limitation. Data for primary production in oligotrophic waters of central parts of subtropical areas of the oceans are rated between $50 \mathrm{mg}$ C. $\mathrm{m}^{-2}$. day ${ }^{-1}$ and more than $1000 \mathrm{mg} \mathrm{C} \cdot \mathrm{m}^{-2}$. day ${ }^{-l}$ in neritic waters (RYTHER 1969). In estuaries more than $2000 \mathrm{mg} \mathrm{C} . \mathrm{m}^{-2}$. day ${ }^{-1}$ were measured (KOBLENTZ -MISCHKE et al 1970). In mixed diatom populations, fertilized with sewage effluent, up to $5 \mathrm{~g} \mathrm{C} . \mathrm{m}^{-2}$. day ${ }^{-1}$ could be found (DUNSTAN \& TENORE 1972) and

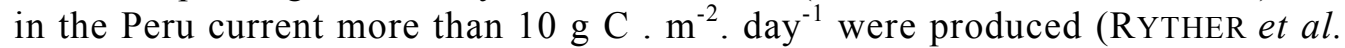
1971). This is already considerably above the value of $1000 \mathrm{mg} \mathrm{C} \cdot \mathrm{m}^{-2}$. day ${ }^{-1}$, measured in pure log. -scale cultures of the large diatom Coscinodiscus asteromphalus (calculated from data in WERNER 1971 a, b) but still significantly less than found with the small size diatom Cyclotella cryptica with $50 \mathrm{~g} \mathrm{C} \cdot \mathrm{m}^{-2}$. day ${ }^{-1}$ (calculated from WERNER 1969). This production with Cyclotella cryptica was achieved with an illumination of about 20,000 lux with a cell density of about $10^{7}$ cells. $\mathrm{ml}^{-1}$. This concentration is sufficient, to give a total absorption of light within a depth of $20 \mathrm{~cm}$. A culture of this density is the theoretical maximum for the production by photosynthetic phytoplankton cells. The estimate, that only about $0.2 \%$ of the energy of the light, penetrating the upper layer of the oceans is used in marine photosynthesis (STEEMANN NIELSEN 1975) with an average of about $100 \mathrm{mg} \mathrm{C} . \mathrm{m}^{-2}$. day ${ }^{-1}$ in the oceans is in good agreement with our data from the culture with Cyclotella cryptica, in which a production of $50 \mathrm{~g} \mathrm{C} \cdot \mathrm{m}^{-2}$. day ${ }^{-1}$ is correspondent with a total absorption of light.

\section{Measurement of production by the ${ }^{14} \mathrm{CO}_{2}$ method and the reproduction of cells and species.}

The classical ${ }^{14} \mathrm{CO}_{2}$ method of measuring the primary production by photosynthetic phytoplankton, introduced in 1952 by STEEMANN NIELSEN, has been extensively used in the meantime. Technical improvements (STEEMANN NIELSEN 1952, SCHINDLER et al 1972; STEEMANN NIELSEN et al. 1974) and restrictions (SHARP \& RENGER 1973; VOLLENWEIDER 1974) have been reported and discussed. Obviously the ${ }^{14} \mathrm{C}$-method measures photosynthesis in the standing stock of a given phytoplankton community 


\section{PRODUCTIVITY OF DIATOMS IN CULTURE}

or a given culture vessel and not reproduction and potential growth. The great usefulness of this standard method for the measurement of photosynthesis of phytoplankton has not to be emphasized here. From this point of view the simple question arises, how primary production depends on reproduction, that includes activity and synthesis of the photosynthetic apparatus, activity and synthesis of enzymes and activity and synthesis of the regulating biomembranes.

TABLE 1. Comparison of photosynthetic production and reproduction in the centric marine diatom Cyclotella cryptica in nutrient $\left(\mathrm{Si}(\mathrm{OH})_{4}\right)$ limited and not limited cells.

Cellular parameters : 5 h generation time; 86 pg dry weight per cell; cell size $\quad: 9 \times 8$ um;

\begin{tabular}{lcc}
\hline & Growing cells & $\mathrm{Si}(\mathrm{OH})_{4}-$ deficient cells \\
\hline $\begin{array}{l}\text { 1. Photosynthetic rate } \\
\left(\mathrm{pg} \mathrm{C.} \mathrm{h}^{-1} \cdot 1^{-1}\right) \text { at zero time }\end{array}$ & 50 & 40 \\
2. after $10 \mathrm{~h}$ & 200 & 20 \\
3. (division per day) & 4.8 & 0 \\
4. Ratio $2 / 3$ & 42 & $\infty$ \\
\hline
\end{tabular}

Table 1 represents some data to illustrate, how photosynthetic rate and cellular reproduction vary in growing cells and in nutrient deficient cells in the marine centric diatom Cyclotella cryptica. Photosynthesis is only slightly different in growing cells and cells in the beginning of $\mathrm{Si}(\mathrm{OH})_{4}$ deficiency for an equal number of cells $.1^{-1} \cdot 10 \mathrm{~h}$ later the factor for cell reproduction and for photosynthetic activity $\mathrm{h}^{-1}$. $1^{-1}$ has multipled by a factor of 4 . In $\mathrm{Si}(\mathrm{OH})_{4}$ deficient cells, reproduction has dropped to zero, while the photosynthetic activity has dropped only to about one half. The ratio of both parameters is absolutely different in both suspensions (Table 1). But mineral nutrition is only one factor, which influences photosynthesis and reproduction of diatom cells to a different extent. Figure 1 summarizes these factors. 


\section{DIETRICH WERNER \& RICHARD ROTH}

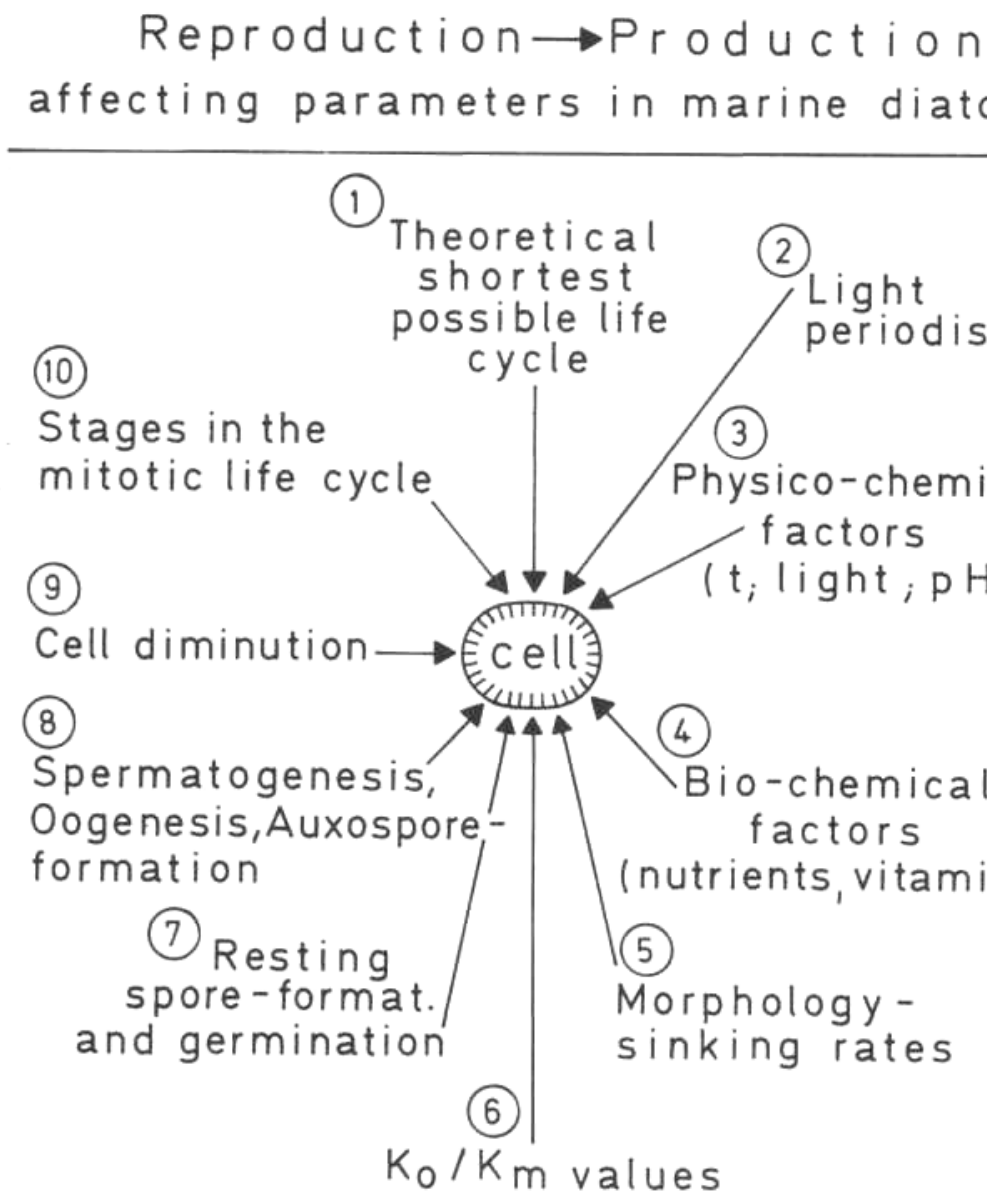

Figure 1. Reproduction-production affecting parameters in marine diatoms. 
1) The theoretical shortest possible life cycle (doubling time) of a species is a basic parameter. It determines the potential reproduction and thereby the maximal rate of the development of a phytoplankton bloom. But as yet, we have not sufficient knowledge of which molecular event in the cells determines the shortest possible life cycle. The synthesis of the DNA-starter protein, the m-RNA synthesis, the synthesis of the precursors of membrane phospholipids, the morphogenesis of special cell structures and many others could be determining. In 1970 WERNER showed for two diatom species with growth rates $(\mu)$ different by a factor of 5 , that the quotient of the protein content of the cells divided by the DNA content and the generation time was very similar for both species. Since under light saturation most photosyn-thetic plankton species accumulate carbohydrates or other storage products, the rate of photosynthesis is not limiting.

2) Light periodism affects the growth of small and large diatom cells in quite a different way. Coscinodiscus asteromphalus (valve diameter between 220 and $60 / \mu \mathrm{m}$ ) needs at least $14 \mathrm{~h}$ of light and $10 \mathrm{~h}$ dark to complete a cell cycle within $24 \mathrm{~h}$, while Cyclotella cryptica (7-11 jum valve diameter) completes 3 cycles within the same time with a light-dark regime of 4:4 h (WERNER 1966).

3) The physico-chemical factors in the sea such as temperature, salinity and $\mathrm{pH}$ affect photosynthetic production and reproduction to different extents in several hundred important phytoplankton species. It is still useful to study e.g. the influence of temperature and salinity on photosynthesis and reproduction of more species, since compared to other unicellular algae, our knowledge of photosynthesis of diatoms is still rather scarce (JORGENSEN 1976)

4) The biochemical factors are the supply of at least 20 essential elements, several vitamins and organic factors (EPPLEY 1976). Additionally, we have to assume, that several species, which we are so far unable to cultivate, may need still other unknown growth factors. Each of these factors can influence photosynthesis and reproduction in a differential way, as shown in the comparison of a $\mathrm{Si}(\mathrm{OH})_{4}$ deficient and a growing suspension of Cyclotella cryptica in Table 1.

5) The interrelationship of cell and shell morphology and that of shape of cell colonies to the sinking rates and the buoyancy of diatoms is one of 


\section{DIETRICH WERNER \& RICHARD ROTH}

the most complicated questions (SMAYDA1974, WERNER \& STANGIER 1976). We are still unable to calculate exactly the sinking rate from a known cell shape, e.g. with long spines, a known specific weight of the cell and the known physical parameters of the water. The sinking rate, of course, changes the influence of many physico-chemical factors such as light, temperature and of biochemical factors such as macronutrient supply on the cells. Special attention should be drawn to connections by gelatinous material, almost invisible in the light microscope. These connect cells in a population which seem to be single cells. By filtering the suspension through a Perlon sieve with 5-10 times larger holes compared to the cell diameter, and the increase of the retained cells after filtration of a mutant strain of Cyclotella cryptica (WERNER 1976), the strength of these connections was shown. Perhaps growth rate and photosynthesis will be affected to different extents in more or less connected cells.

6) $\mathrm{K}_{\mathrm{o}}$ values (the minimum external concentration of an ion, below which no uptake can occur) and the $\mathrm{K}_{\mathrm{S}}\left(\mathrm{K}_{\mathrm{m}}\right)$ values by a species are of special importance for the succession of species under nutrient limitation (Dugdale 1967; Hellebust \& Guillard 1967; PAasche 1973). But so far, we have almost no information, how the $K_{o}$ and $K_{s}$ values for phosphate, combined nitrogen or silicate uptake are related to the efficiency of photosynthesis under nutrient limitation.

7) The formation and germination of resting spores is of special importance in areas with a wide range of different physico-chemical factors such as shore lines and estuaries with high and low tides, salinity variation and temperature changes. This adaptation to unfavourable conditions by a certain species under those conditions is more vital for the survival and also for the fast recovery than many other parameters, listed here. We found, that less than $0.01 \%$ of the cells of Cyclotella cryptica with an upper temperature growth limit of $32^{\circ} \mathrm{C}$, could survive a treatment of $30 \mathrm{~min}$. at $47^{\circ} \mathrm{C}$ (WERNER 1970). But it is not certain, so far, that this surviving fraction is identical with morphologically characterized resting spores.

8) The induction of sexual development in marine centric diatoms is one of the most fascinating developmental events in these unicellular organisms, which profoundly influences almost all major biochemical activities and cytological qualities of the cells. Since spermatogenesis is 


\section{PRODUCTIVITY OF DIATOMS IN CULTURE}

much better studied than oogenesis, we will mention here some steps in its development in Coscinodiscus asteromphalus (WERNER 1971 a, b, c,). At a critical cell size and by induction through a temperature rise and increase in light intensity the vegetative cell can change to a spermatogonangium with up to 32 spermatogonia. These develop further to spermatocytes. With four sperms coming out of each spermatocyte, we get more than a hundred sperms from one cell. During this development, the chloroplasts can remain intact for a long time, in other species they are autolyzed very soon or ejected from the sperms. Protein synthesis, DNA synthesis, and ${ }^{14} \mathrm{C}$-incorporation in photosynthesis and many other parameters are differentially affected at each stage of the development. On the other hand, a successful zygote formation and auxospore development is the starting point of a new generation of genetically identical cells with a high growth rate and metabolic activity. A calculation revealed, that in Coscinodiscus asteromphalus a single auxospore formation could result, with an undisturbed vegetative growth, in a biomass of $10^{10} \mathrm{t}$, before a next sexual event is necessary (WERNER 1971 a).

9) This remark leads already to the next point, a unique feature of most diatom species, the diminution of the valve diameter according to the MAC DONALD PFITZER rule. During this development of the cell line, an extensive differentiation at the unicellular level takes place. Various components and activities of the cells are reduced to different extents. During this development, also the sensitivity towards several metabolic inhibitors changes significantly, indicating again a differentiation of the cells (WERNER 1971 b).

10) Besides such stages in the sexual life cycle, the diatom species have stages with varying activities in the mitotic life cycle as other unicellular algae (SENGER 1970). The different rates of ${ }^{14} \mathrm{C}$ incorporation in the light for two stages in the mitotic life cycle of Coscinodiscus asteromphalus are shown in Figure 2. The activity per $\mu g$ cell protein is about $30 \%$ reduced in cells from stages 6 hours after the beginning of the dark period compared to cells from stages 5 hours earlier. This single factor means, that planktonical field studies can vary by $30 \%$, depending from the hour of the day the samples were collected. 
DIETRICH WERNER \& RICHARD ROTH

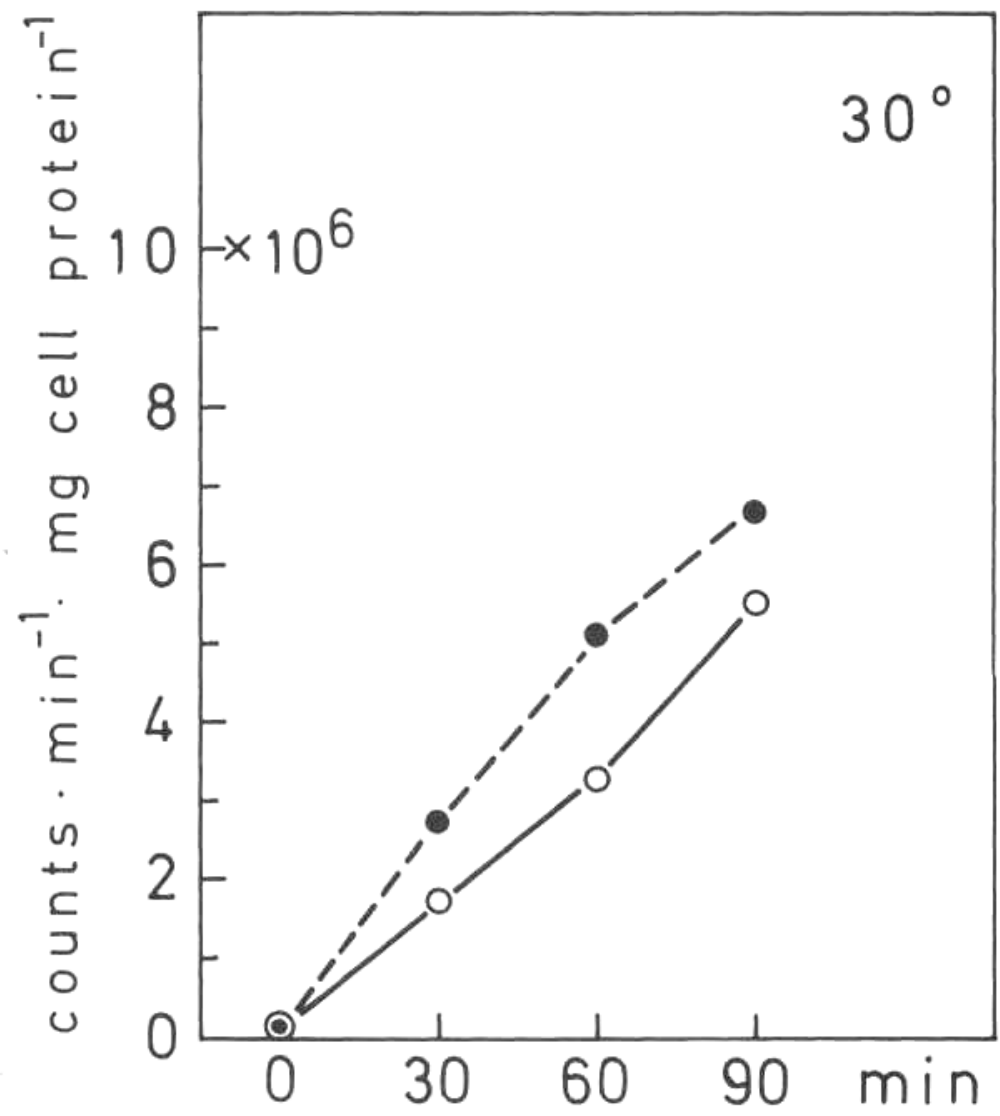

Figure 2. ${ }^{14} \mathrm{C}$ incorporation in Coscinodiscus asteromphalus, partially synchronized in a $14: 10 \mathrm{~h}$ light-dark regime. Addition of $160 \mu \mathrm{Ci} / 1$ sodium- ${ }^{14} \mathrm{C}$-bicarbonate, specific activity 55 $\mu \mathrm{Ci} /$ umol; 2000 ex during incorporation experiments. $\mathrm{t} 30^{\circ} \mathrm{C}$.

$\mathrm{o} \longrightarrow$ cells from $1 \mathrm{~h}$ dark regime $\mathrm{o}-\ldots$ o cells from $6 \mathrm{~h}$ dark regime.

3. The culture of Bellerochea yucatanensis

As an example of the need for more information about the qualities of single species from less studied areas of the oceans such as the tropical shallow waters, the culture of Bellerochea yucatanensis is described. This species was isolated from the coast of Yucatan (WERNER \& STANGIER 1976) and described by v. STOSCH (1976). First, the maximum growth temperature was studied and found to be between 35 and $37^{\circ} \mathrm{C}$ (Fig. 3). In these cultures the cells were grown in $50 \mathrm{ml}$ Erlenmeyer flasks with $20 \mathrm{ml}$ medium without additional aeration. The growth of the cells stopped at a maximum density of about $4 \times 10^{4}$ cells. $\mathrm{ml}^{-1}$ at $29^{\circ}$ and also at $20^{\circ} \mathrm{C}$. The tolerance 
PRODUCTIVITY OF DIATOMS IN CULTURE

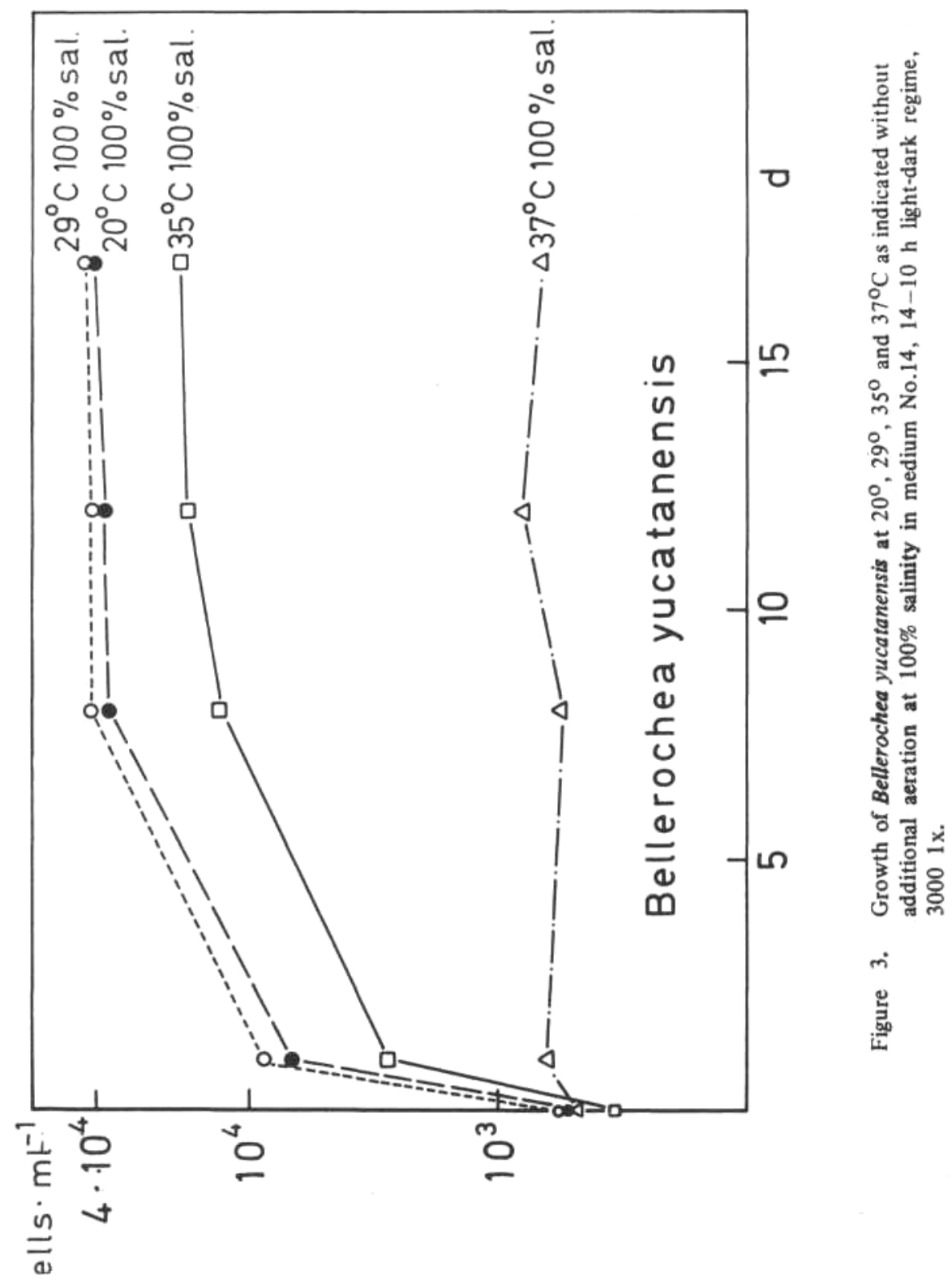




\section{DIETRICH WERNER \& RICHARD ROTH}

for a reduction of salinity by $50 \%$ is small (Fig. 4). Only 2 to 3 cell divisions take place at $20^{\circ}$ and $29^{\circ} \mathrm{C}$ under these conditions. To increase the maximum growth rate we tried to cultivate this species in a liglit-thermostat with continuous aeration $\left(1.5 \%(\mathrm{v} / \mathrm{v}) \mathrm{CO}_{2}\right.$ in air). As shown in Figure 5, the $\mathrm{pH}$ of the sea water medium drops, without the addition of buffer within $4 \mathrm{~h}$ from $\mathrm{pH} 8.0$ to 6.8 (Fig. 5). A concentration of $0.02 \mathrm{M}$ TRIS-HC1 ( $\mathrm{pH} \mathrm{8.0)} \mathrm{buffer} \mathrm{reduced} \mathrm{this} \mathrm{fall} \mathrm{to}$ about 7.5. Only the supply of $0.2 \mathrm{M}$ leaves the medium $\mathrm{pH}$ unchanged.

Adding a concentration of $0.02 \mathrm{M}$ TR1S-HC1 buffer was already sufficient, to give a remarkably rapid growth of Bellerochea yucatanensis with a generation time of $6 \mathrm{~h}$ at $34^{\circ}$ ( $\mu \max 4$ divisions per day) and at $30^{\circ} \mathrm{C} \mathrm{M}$ max of 4.4 in the culture with continuous aeration (Figure 6). Under these conditions, the maximum cell number per $\mathrm{ml}$ is about 5 times higher $\left(2.5 \times 10^{5}\right.$ cells, $\left.\mathrm{ml}^{-7}\right)$ than in the culture not continuously aerated (Fig. 3). The limitation towards higher temperature is rather sharp. At $35^{\circ} \mathrm{C} \mu$ max is only 2 , at $36^{\circ} \mathrm{C}$ no increase in cell number is observed.

In relation to the cell size of $34 \mu \mathrm{m}$ pervalvar axis and $26 \mu \mathrm{m}$ valve diameter average values a $\mu$ max of 4.4 divisions per day is remarkable high. The highest specific growth rates reported so far for diatoms were 5-6 divisions per day for Chaetoceros gracilis (THOMAS 1966) 5 divisions per day for Cylcotella cryptica (WERNER 1966) and 4.3 divisions per day for Skeletonema costatum (CURL \& MCLEOD 1961). But these species are considerably smaller.

On the basis of these results, Bellerochea yucatanensis seems to be a very useful physiological object for further studies of tropical marine phytoplankton potential. This species might also be an appropriate subject for experiments of induction of sexual development by high temperature and light.

\section{CONCLUSIONS}

It is obvious from Figure 1, that production and reproduction are strongly influenced by many often interrelated factors. This poses the question as to which measurable biochemical parameter best represents these two qualities of phytoplankton cells, which as we have seen, should properly be considered together. In the authors opinion, a method should be developed of the rapid assessment of some biochemical process, which connects more closely the light dependent supply of carbohydrate to the protein synthesizing machinery of the cells. It is proposed to work out a 
PRODUCTIVITY OF DIATOMS IN CULTURE

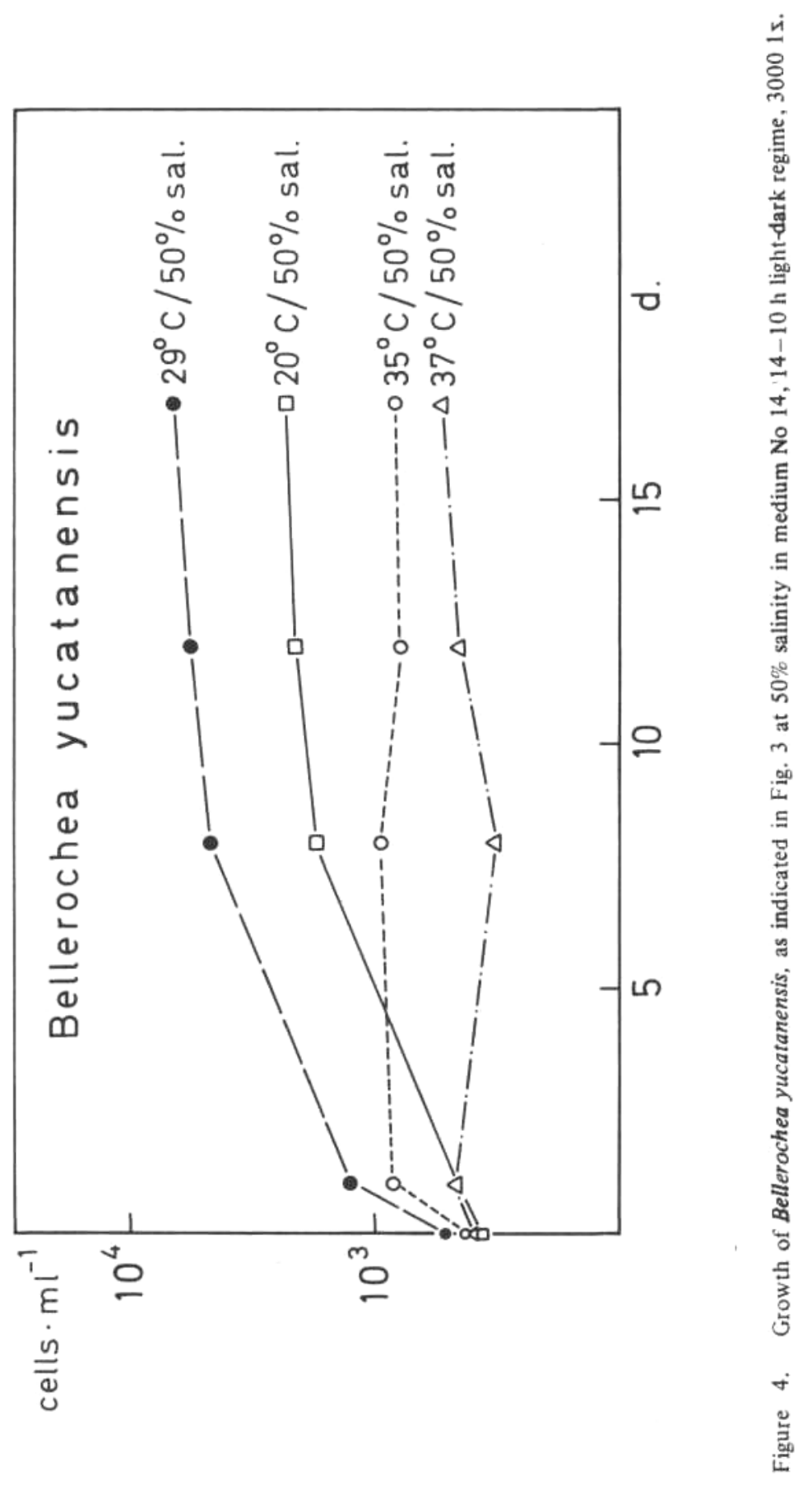




\section{DIETRICH WERNER \& RICHARD ROTH}

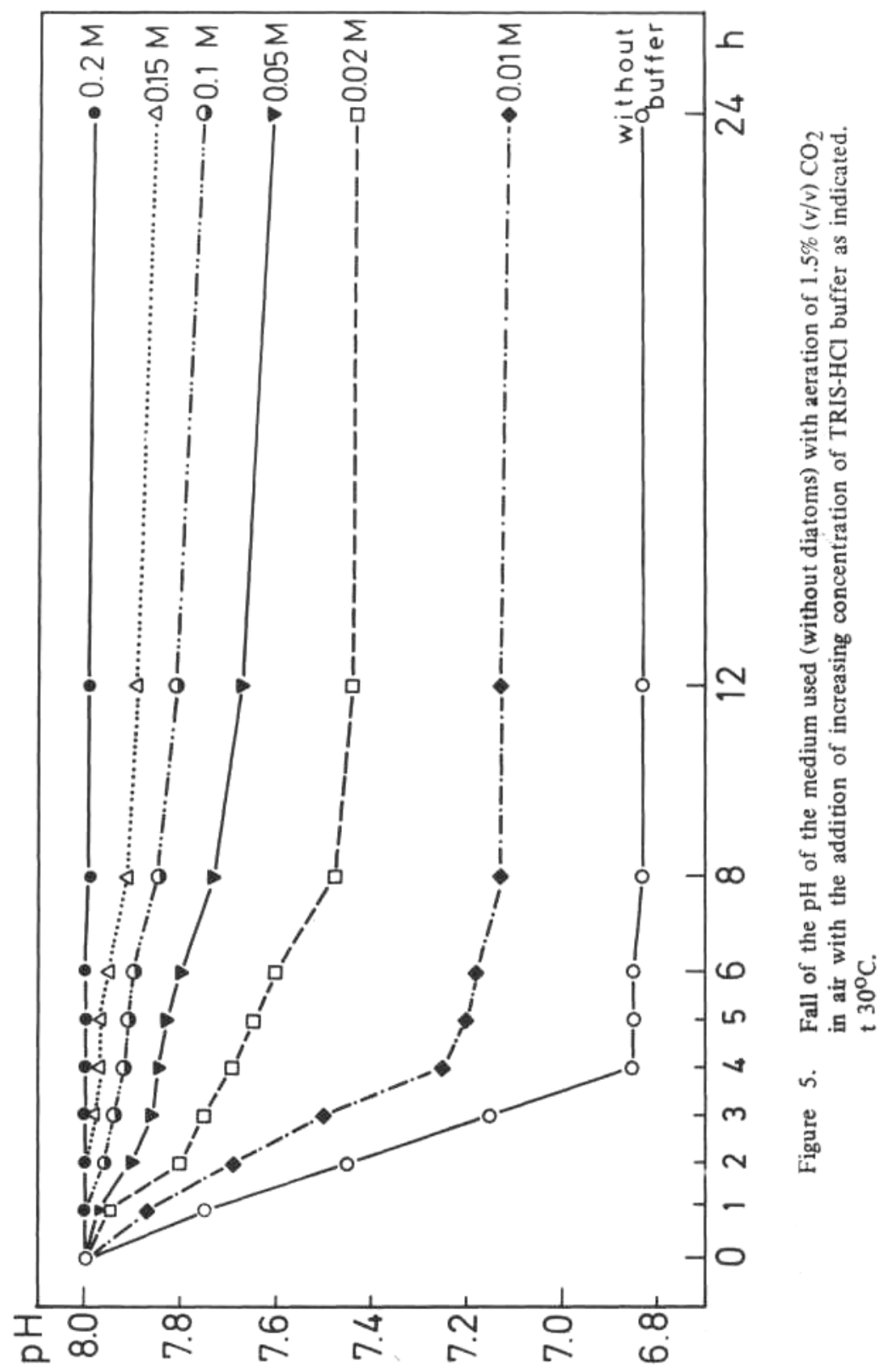


PRODUCTIVITY OF DIATOMS IN CULTURE

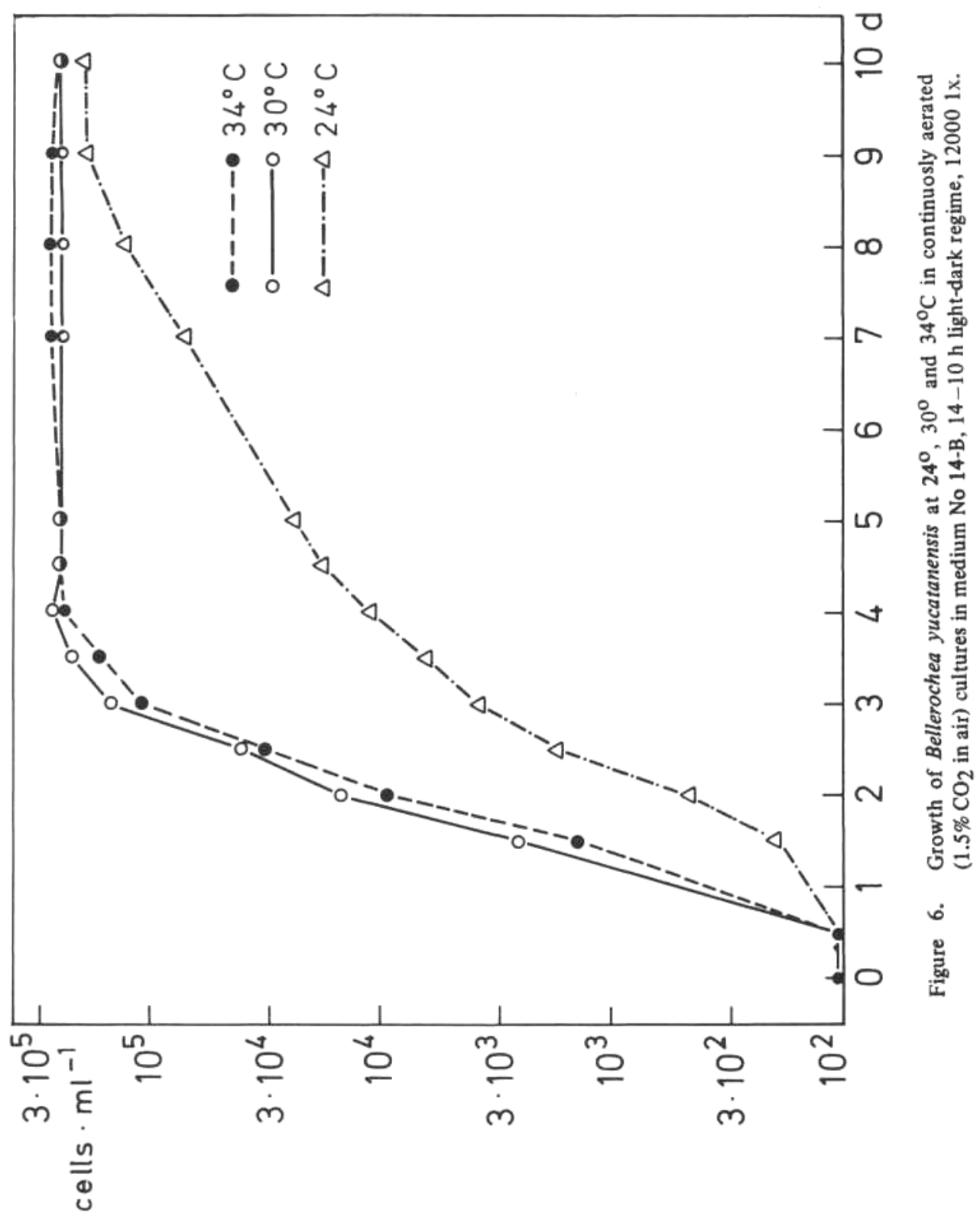




\section{DIETRICH WERNER \& RICHARD ROTH}

rapid assay for light dependent protein synthesis, to exclude the protein synthesis of not photosynthetic cells and thus to include $\mathrm{C}$ and $\mathrm{N}$ metabolism.

\section{ACKNOWLEDGEMENT}

We thank the Deutsche Forschungsgemeinschaft for the support in grants No. We 200/10 and 477/3/76.

\section{REFERENCES}

CURL, JR. H. and G. C. MCLEOD 1961. The physiological ecology of a marine diatom Skeletonema costatum (GREV.) CLEVE. J. Mar. Res. 19:70-88.

DUCDALE, R. C. 1967. Nutrient limitation in the sea: dynamics, identification and significance. Limnol. Oceanogr. 12:685-695.

DUNSTAN, W. M. and K. R. TENORE 1972. Intensive outdoor culture of marine phytoplankton enriched with treated sewage effluent. Aquaculture 1:181-192.

EPPLEY, R. W. 1976. The growth and culture of diatoms. In: The Biology of Diatoms (D. WERNER ed.). Blackwell Scientif. Publ., Oxford: 24-63.

HELLEBUST, J. A. and R. R. L. GUILLARD 1967. Uptake specificity for organic substrates by the marine diatom Melosira nummuloides. J. Phycol. 3:132-136.

JORGENSEN, E. G. 1976. Photosynthesis. In: The Biology of Diatoms (D. WERNER ed.). Blackwell Scientific Publ., Oxford: 150-168.

KOBLENTZ-MISHKE, O. J.; V. V. VOLVINSKY and J. G. KABANOVA 1970. Plankton primary production of the world ocean. In: Scientific Exploration of the South Pacific (W. S. WOOSTER ed.) Natl. Acad. Science, Washington D.C.: 183-193.

PAASCHE, E. 1973. Silicon and the ecology of marine plankton diatoms. I. Thalassiosira pseudonana (Cyclotella nana) growth in a chemostat with silicate as limiting nutrient. Mar. Biol. 10:117-126.

RHYTHER, J. H. 1969. Photosynthesis and fish production in the sea. Science 166:72-76.

RYTHER, J. H.; D. W. MENZEL; E. M. HILBURT; C. J. LORENZEN and N. CORVIN 1971. The production and utilization of organic matter in the Peru coastal current. Inv. Pesq. 35:43 59.

SCHINDLER, D. W.; R. V. SCHMIDT and R. A. REID 1972. Acidification and bubbling as an alternative to filtration in determining phytoplankton production by the ${ }^{14} \mathrm{C}$ method. J. Fish. Res. Board Can. 29:1627-1631.

SENGER, H. 1970. Charakterisierung einer Synchronkultur von Scenedesmus obliquus, ihrer potentiellen Photosyntheseleistung und den Photosynthesequotienten wahrend des Entwick-lungszyklus. Planta (Berl.) 90:243-266.

SHARP, J. H. and E. H. RENGER 1973. Extracellular production of organic matter by marine phytoplankton. Inst. Mar. Resource Progr. Rep. July 72-June 73:69-72. 


\section{PRODUCTIVITY OF DIATOMS IN CULTURE}

SMAYDA, T. J. 1974. Some experiments on the sinking characteristics of two freshwater diatoms. Limnol. Oceanogr. 19:628-635.

STEEMANN NIELSEN, E. 1952. The use of radioactive carbon $\left(\mathrm{C}^{14}\right)$ for measuring organic production in the sea. J. Cons. Int. Explor. Mer. 18:117-140.

STEEMANN NIELSEN, E.; S. WIUM-ANDERSEN and T. ROCHON 1974. On problems in G.M. countings in the $\mathrm{C}^{14}$-technique. Congr. Int. Assoc. Limnol., Winnipeg 1974: 198 pp.

STEEMANN NIELSEN, E. 1975. Marine photosynthesis. With special emphasis on the ecological aspects. Elsevier Publ. Comp., Amsterdam: 141 pp.

STOSCH V., H.A. 1976. Remarks on Bellerochea and Strep to theca including three new or possibly new planktonic diatom species. 4. Symposium on recent and fossil marine diatoms. Oslo 1976. Beih. Nova Hedwigia (in press).

THOMAS, W. H. 1966. Effects of temperature and illuminance on cell division rates of three species of tropical oceanic phytoplankton. J. Phycol. 2:17-22.

VOLLENWEIDER, R. A. (ed) 1974. A manual on methods for measuring primary production in aquatic environments. IBP Handbook No 12. Blackwell Scientific Publ., Oxford, 2. ed.: 213 pp.

WERNER, D. 1966. Die Kieselsaure im Stoffwechsel von Cyclotella cryptica Reimann Lewin und Guillard. Arch. Mikrobiol. 55:278-308.

WERNER, D. 1969. Beitrage zur Physiologie und Biochemie der Kieselsaure. Ber. dt. bot. Ges. 81:425429.

WERNER, D. 1970 a. Productivity studies on diatom cultures. Helgolander wiss. Meeresunters. 20:97-103.

WERNER, D. 1970 b. Isolierung einer Gallertkolonien bildenden Mutante von Cyclotella cryptica nach Temperature-schockbehandlung. Intern. Rev. ges. Hydrobiol. 55:403-407.

WERNER, D. 1971 a. Der Entwicklungszyklus mit Sexualphase bei der marinen Diatomee Coscinodiscus asteromphalus. I. Kultur und Synchronisation von Entwicklungsstadien. Arch. Mikrobiol. 80: 43-49.

WERNER, D. 1971 b. Der Entwicklungszyklus mit Sexualphase bei der marinen Diatomee Coscinodiscus asteromphalus. II. Oberflachenabhangige Differenzierung wahrend der vege-tativen Zellverkleinerung. Arch. Mikrobiol. 80:115-133.

WERNER, D. 1971 c. Der Entwicklungszyklus mit Sexualphase bei der marinen Diatomee Coscinodiscus asteromphalus. III. Differenzierung und Spermatogenese. Arch. Mikrobiol. 80:134146.

WERNER, D. and E. STANGIER 1976. Silica and temperature dependent colony size of Bellerochea malleus f. biangulata. Phycologia 15:73-77. 